\title{
Analisis Pendapatan Usaha Ternak Domba Secara Intensif di Kabupaten Cirebon
}

\section{Income Analysis Business Sheep Livestock of Intensive in the Cirebon Districts}

\author{
F. D. Perwitasari* dan Bastoni \\ Universitas Muhammadiyah Cirebon \\ J.1. Fatahila No. 40 Watubelah, Kecamatan Sumber, Kabupaten Cirebon \\ *E-mail: caraka20@gmail.com \\ (Diterima: 17 Oktober 2019; Disetujui: 21 Januari 2019)
}

\begin{abstract}
ABSTRAK
Kelompok Tani Ternak Haur Kuning berada di desa Ciawigajah Kabupaten Cirebon. Kelompok ini tata laksana pemeliharaan secara intensif dan masih bisa bertahan walaupun dari sisi produksinya kurang maksimal. Produksi yang kurang maksimal akan menjadi kendala dalam memperoleh pendapatan. Oleh sebab itu, penelitian ini bertujuan untuk mengetahui berapa pendapatan dari usaha ternak domba selama satu tahun buku atau siklus untuk mengetahui faktor harga jual, jumlah ternak yang dijual dan biaya pakan yang mempengaruhi besarnya pendapatan. Metode penentuan lokasi dengan purposive sampling. Metode purposive sampling yaitu pemilihan lokasi dipilih secara sengaja oleh peneliti karena kelompok tani ternak Haur Kuning memiliki sistem pemeliharaan domba secara intensif dan merupakan kelompok domba yang masih bertahan di Kabupaten Cirebon. Metode Pengumpulan data dalam penelitian ini menggunakan wawancara dan observasi. Data primer berasal dari pengamatan langsung dan hasil wawancara dengan kelompok mengenai aspek teknis dan keuangan (dalam satu tahun buku atau siklus). Data sekunder berasal dari Dinas Pertanian Kabupaten Cirebon dan literatur (jurnal penelitian, buku, dan artikel ilmiah). Hasil wawancara (secara teknis dan keuangan) kemudian dianalisis dengan menggunakan rumus analysis pendapatan dan regresi berganda. Hasil dari penelitian ini menunjukan rata-rata pendapatan yang diterima dalam satu tahun sebesar Rp 2.979.456 dengan rata-rata penjualan ternak domba 3 ekor, rata-rata $\mathrm{R} / \mathrm{C}$ ratio sebesar 2,83 . Pendapatan yang diterima berpengaruh nyata terhadap harga jual ternak, jumlah ternak yang dijual dan biaya pakan.
\end{abstract}

Kata kunci: analisis pendapatan, $\mathrm{R} / \mathrm{C}$ ratio, regresi, ternak domba intensif

\section{ABSTRACT}

The Group Haur Kuning Farmer is in the village of Ciawigajah, Cirebon District. This group is maintenance intensive and can still survive even though the production is not optimal. Maximum production will be an obstacle in obtaining income. Therefore, this study aims to determine how much income from sheep business for one financial year or cycle, to determine the selling price factor, the number of livestock sold and feed costs that affect the amount of income. The method of determining the location by purposive sampling. The purposive sampling method is the selection of locations deliberately chosen by researchers because the Haur Kuning livestock farmer group has an intensive sheep-raising system and is a group of sheep that still survive in Cirebon District. The method of data collection in this study used interviews and observation. Primary data comes from direct observation and the results of interviews with groups regarding technical and financial aspects (in one book year or cycle). Secondary data came from the Cirebon District Agricultural Service and literature (research journals, books, and scientific articles). The interview results (technically and financially) were then analyzed using the income analysis formula and multiple regression. The results of this study show that the average income received in one year is IDR. $2,979,456$ with an average sale of sheep 3 tails, the average $R / C$ ratio is 2.83. The income received has a significant effect on the selling price of livestock, the number of livestock sold and the cost of feed.

Keywords: income analysis, intensive sheep livestock, $R / C$ ratio, regression 


\section{PENDAHULUAN}

Domba merupakan ternak ruminansia kecil yang mempunyai fungsi secara ekonomi (Sebagai penyumbang perekonomian keluarga sebagai tabungan, tambahan dan memenuhi kebutuhan finansial yang mendadak) dan pemenuh kebutuhan protein hewani.

Kabupaten Cirebon memiliki jumlah populasi domba sebanyak 236.264 ekor yang tersebar di seluruh wilayah Kabupaten cirebon. Masyarakat Kabupaten Cirebon memilih ternak domba untuk dibudidayakan dengan alasan: 1) domba mudah dalam pemberian pakan, 2) mampu beradaptasi di Kabupaten Cirebon memiliki suhu berkisaran antara $\left(22{ }^{\circ} \mathrm{C}-30{ }^{\circ} \mathrm{C}\right)$. 3) memanfaatkan waktu luang. Menurut Erwidodo, 1995 yang dikutip dari (Siswati et al., 2015) mengatakan bahwa ternak domba dilihat secara teknis mempunyai sifat toleransi tinggi terhadap macam-macam hijauan, adaptasi lingkungan yang baik dan perputaran modalnya cepat dikarenakan mudah dalam pemasarannya.

Kelompok Tani Ternak Haur Kuning terletak di desa Ciawigajah Kecamatan Beber Kabupaten Cirebon merupakan suatu lokasi kelompok tani ternak domba yang pemeliharaannya sudah secara intensif dengan jumlah kepemelikan ternak bervariasi. Peranan Ternak domba di kelompok tani ternak Haur Kuning sebagai pendapatan tambahan peternak atau sebagai tabungan, sebagai salah satu komoditas peternakan, sebagai sumber protein hewani bagi masyarakat, pengisi waktu, pemanfaatan pekarangan dan kotoran sebagai pupuk kandang. Kendala dalam pemeliharaan ternak domba masih tradisional, pemberian pakan yang hanya bergantung dengan kesediaan alam dan limbah pertanian yang ada di lingkungan sekitar tanpa memperhatikan kebutuhan standar gizi ternak. Pemeliharaan secara tradisional ini masih bisa bertahan walaupun dari sisi produksinya kurang maksimal.

Produksi yang kurang maksimal akan menjadi kendala dalam memperoleh pendapatan. Untuk mengetahui pendapatan harus diketahui dulu tentang biaya total produksi yang dikeluarkan. Penelitian tentang analisis pendapatan di Kelompok tani ternak sangat diperlukan. Oleh sebab itulah, penelitian ini bertujuan untuk mengetahui berapa pendapatan dari usaha ternak domba selama satu tahun buku atau siklus, untuk mengetahui faktor harga jual, jumlah ternak yang dijual dan biaya pakan yang mempengaruhi besarnya pendapatan.

\section{METODE}

Penelitian ini dilakukan di Kelompok Tani Ternak Haur Kuning Desa Ciawigajah Kecamatan Beber Kabupaten Cirebon pada bulan Maret - Juni 2018. Metode penentuan lokasi secara purposive sampling yaitu pemilihan lokasi dipilih secara sengaja oleh peneliti karena kelompok tani ternak Haur Kuning memiliki sistem pemeliharaan domba secara intensif dan merupakan kelompok domba yang masih bertahan di Kabupaten Cirebon. Metode yang digunakan dalam penelitian ini adalah metode observasi dan wawancara.

Populasi yang digunakan dalam penelitian ini semua anggota Kelompok Tani Ternak Haur Kuning yang memiliki domba. Jumlah anggota responden anggota Kelompok Tani Ternak Haur Kuning adalah 19 orang. Sampel yang digunakan untuk penelitian ditentukan berdasarkan rumus:

$$
\mathrm{n}=\frac{N}{1+N x\left(e^{2}\right)}
$$

Keterangan :

$\mathrm{n}=$ jumlah sampel

$\mathrm{N}=$ jumlah populasi

$\mathrm{e}=$ kesalahan yang ditolerir

$$
\mathrm{n}=\frac{19}{1+19 \times\left(0,2^{2}\right)}=11
$$

1. Variabel yang diukur dalam penelitian ini yaitu: 
a. Pendapatan usaha ternak domba di Kelompok Tani Ternak Haur Kuning dalam satu tahun

b. Biaya produksi usaha ternak domba di Kelompok Tani Ternak Haur Kuning dalam setahun

2. Faktor-faktor yang mempengaruhi pendapatan usaha ternak domba di Kelompok Tani Ternak Haur Kuning, yaitu:

a. Harga jual ternak (Rupiah),

b. Jumlah ternak yang dijual (Ekor)

c. Biaya pakan (Rupiah)

Data primer diperoleh dari hasil observasi dan wawancara dengan anggota kelompok Tani Ternak Domba Haur Kuning. Wawancara dengan anggota kelompok tani ternak disusun sesuai dengan tujuan penelitian. Data sekunder berasal dari Dinas Pertanian Kabupaten Cirebon dan literatur jurnal penelitian, buku, artikel ilmiah. Data yang terkumpul dari wawancara responden kemudian dianalisis dengan mengunakan tabulasi, dihitung menggunakan rumus pendapatan, analisis $\mathrm{R} / \mathrm{C}$ ratio dan analisis regresi berganda dan di jelaskana secara deskriptif .

Rumus Pendapatan (Soekartawi, 1996) :

$$
\mathrm{Pd}=\mathrm{TR}-\mathrm{TC}
$$

Keterangan:

Pd $=$ Total Pendapatan yang diterima oleh anggota kelompok tani ternak Haur Kuning (Rupiah/tahun)

$\mathrm{TR}=$ Total Revenue (Total Penerimaan) yang diterima oleh anggota kelompok tani terak Haur Kuning (Rupiah/tahun)

$$
\mathrm{TR}=\mathrm{Py} \mathrm{x} \mathrm{Y}
$$

Keterangan:

$\mathrm{Y}=$ Jumlah unit ternak dijual dari usaha ternak domba

Py $=$ Harga jual ternak

$\mathrm{TC}=$ Total Cost (Total Biaya Produksi) yang dikeluarkan oleh anggota kelompok tani ternak Haur Kuning (Rupiah/ tahun)

$$
\mathrm{TC}=\mathrm{FC}+\mathrm{VC}
$$

Keterangan:

$\mathrm{FC}=$ Total Biaya Tetap yang dikeluarkan oleh anggota kelompok tani ternak Haur Kuning (Rupiah/tahun)

$\mathrm{VC}=$ Total Biaya variabel yang dikeluarkan oleh anggota kelompok tani ternak Haur Kuning (Rupiah/tahun)

Analisis $\mathrm{R} / \mathrm{C}$ ratio

Untuk mengetahui berapa besar penerimaan yang akan diperoleh dari setiap rupiah yang akan dikeluarkan oleh petani untuk kegiatan usaha ternak domba.

Rumus R/C ratio (Pasaribu, 2012):

$$
\mathrm{R} / \mathrm{C} \text { ratio }=\mathrm{TR} / \mathrm{TC}
$$

Dimana:

$\mathrm{R} / \mathrm{C}=$ imbangan penerimaan dan biaya

$\mathrm{TR}=$ Penerimaan total

$\mathrm{TC}=$ Biaya Total

Untuk mengetahui pengaruh faktorfaktor yang berpengaruh terhadap besarnya pendapatan dilakukan Analisis Regersi Linier Berganda dengan model persamaan sebagai berikut:

$$
\mathrm{Y}=\mathrm{a}+\mathrm{b}_{1} \mathrm{X}_{1}+\mathrm{b}_{2} \mathrm{X}_{2}+\mathrm{b}_{3} \mathrm{X}_{3}
$$

Keterangan:

$\mathrm{Y}=$ Pendapatan

$\mathrm{a}=$ Intercept

$\mathrm{X} 1$ = Harga jual ternak domba anggota kelompok tani ternak Haur Kuning (rupiah/tahun)

$\mathrm{X} 2$ = Jumlah ekor ternak domba anggota kelompok tani ternak Haur Kuning yang dijual (rupiah/tahun)

X3 = Biaya Pakan yang dikeluarkan oleh kelompok tani ternak Haur Kuning (Rupiah/tahun)

$\mathrm{X} 4$ = Lama pengalaman beternak domba anggota kelompok tani ternak Haur Kuning

Kemudian diuji dengan uji $t$ test dan uji f test. 
Tabel 1. Karateristik Responden Kelompok Tani Ternak Haur Kuning

\begin{tabular}{|c|c|c|c|}
\hline No & Keterangan & Jumlah & Persentase $(\%)$ \\
\hline & Umur & & \\
\hline 1 & $21-50$ & 9 & 81,82 \\
\hline \multirow[t]{2}{*}{2} & $>51$ & 2 & 18,18 \\
\hline & Tingkat Pendidi & & \\
\hline 1 & Tidak Tamat SD & 1 & 9,09 \\
\hline 2 & $\mathrm{SD}$ & 9 & 81,82 \\
\hline 3 & SMP & 1 & 9,09 \\
\hline 4 & SMU & 0 & 0,00 \\
\hline \multirow[t]{2}{*}{5} & Peguruan Tinggi & 0 & 0,00 \\
\hline & Pengalaman Bet & & \\
\hline 1 & 1- 10 tahun & 6 & 54,55 \\
\hline \multirow[t]{2}{*}{2} & $>10$ tahun & 5 & 45,45 \\
\hline & Tujuan Usaha B & & \\
\hline 1 & Sampingan & 10 & 90,91 \\
\hline 2 & Komersial & 1 & 9,09 \\
\hline 3 & Tabungan & 0 & 0,00 \\
\hline \multirow[t]{2}{*}{4} & Tidak ada & 0 & 0,00 \\
\hline & Mata Pencarian & & \\
\hline 1 & buruh tani & 1 & 9,09 \\
\hline 2 & Bertani & 9 & 81,82 \\
\hline \multirow[t]{2}{*}{3} & Wiraswasta & 1 & 9,09 \\
\hline & Jumlah Ternak & & \\
\hline 1 & $1-5$ & 10 & 90,90 \\
\hline 2 & $6-10$ & 1 & 9,10 \\
\hline 3 & $11-15$ & 0 & 0,00 \\
\hline 4 & $16-20$ & 0 & 0,00 \\
\hline
\end{tabular}

Sumber: Data olahan 2018

\section{HASIL DAN PEMBAHASAN}

\section{Karateristik Responden}

Responden berasal dari anggota kelompok tani ternak Haur Kuning yang memiliki ternak domba. Faktor sumber daya manusia sangat mempengaruhi keberlangsungan kegiatan usaha ternak domba. Oleh sebab itu, karateristik responden anggota kelompok tani ternak Haur Kuning akan dijelaskan di bawah ini meliputi 1) usia, 2) tingkat pendidikan, 3) pengalaman beternak,
4) tujuan beternak, 5) Mata Pencaharian Utama Responden, dapat dilihat lebih jelas pada (Tabel 1).

\section{Umur Responden}

Umur anggota Kelompok Tani Ternak Haur Kuning yaitu antara 21-50 tahun $(81,82 \%)$. Hasil penelitian ini menunjukkan rata-rata anggota kelompok tani ternak masih dalam kisaran umur produktif.. Hasil ini menunjukkan bahwa rata-rata responden masih dalam kisaran umur produktif. Umur Produktif ini masih memiliki tenaga, dan motivasi 
untuk berusaha lebih maju lagi dalam usaha ternak domba (Welerubun et al., 2015). Hal tersebut didukung juga dengan pendapat (Mastuti dan Hidayati, 2009) umur yang produktif ini dapat memudahkan penyerapan pengetahuan, teknologi dan informasi yang disampaikan guna menunjang usaha ternak dan produktivitas domba.

\section{Tingkat Pendidikan}

Hasil penelitian ini menunjukkan tingkat pendidikan mayoritas kelompok tani ternak Haur Kuning yaitu hanya lulusan SD. Rendahnya pendidikan anggota kelompok tani ternak, pengetahuan secara teknis tentang pemeliharaan ternak domba berdasarkan pengalaman peternak turun menurun. Menurut Badar et al. (2014) tingkat pendidikan semakin tinggi akan mempengaruhi kinerja dalam menerima inovasi semakin mudah. Oleh sebab itu responden dalam memberikan tambahan informasi, pengetahuan dan teknologi diberikan pelatihan dan pedampingan secara kontinyu.

\section{Pengalaman Beternak}

Pengalaman beternak anggota kelompok tani ternak Haur Kuning yaitu antara 1 - 10 tahun. Hasil tersebut menunjukkan bahwa anggota kelompok tani ternak Haur Kuning mempunyai ketrampilan dalam mengelola ternak domba dengan baik dari turun-temurun. Pengalaman beternak selama $1-10$ tahun sebenarnya sudah mendapatkan ketrampilan dalam mengelola ternak domba dengan baik (Welerubun et al., 2015).

\section{Tujuan Usaha Beternak}

Hasil penelitian menunjukkan bahwa tujuan usaha beternak hampir mencapai $90 \%$ lebih sebagai usaha sampingan responden. Alasan peternak mengatakan bahwa sebagai usaha sampingan karena 1) memanfaatkan waktu luang, 2) memanfaatkan limbah pertanian peternak untuk pakan ternak, 3) memanfaatkan kotoran domba untuk pupuk.

\section{Mata Pencaharian Utama Responden}

Hasil penelitian menunjukkan bahwa pekerjaan utama anggota kelompok tani Haur Kuning yaitu $81,82 \%$ sebagai Petani. Hasil ini menunjukan bahwa alasan mereka beternak bukan merupakan tujuan utama beternak untuk sambilan. Hal ini didukung dengan pendapat (Siswati et al., 2015) mengatakan responden masih mengangap usaha ternak domba sebagai sumber tambahan pendapatan keluarga selain mata pencaharian utama responden menjadi petani atau buruh tani yaitu 58 orang $(84,6 \%)$.

\section{Jumlah Ternak yang Dijual dalam Setahun}

Hasil penelitian ini menunjukkan bahwa dalam satu tahun terakhir responden rata-rata menjual ternak berkisar antara $1-5$ ekor / tahun sebesar 90,90\%. Hasil penjualan ternak masih dalam jumlah sedikit, alasan dari responden yaitu 1) produksi belum maksimal, baik dari bibit, pakan dan manajemen pemeiharaan 2) responden menjual ternaknya ketika mereka membutuhkan dana, 3) penjualan tidak dilakukan rutin akan tetapi hanya di waktu tertentu saja.

\section{Sistem Pemeliharaan}

Responden dalam sistem pemeliharaan ternak domba sudah menerapkan pola pemeliharaan intensif. Pola Pemeliharaan intensif dimana ternak domba di kandang secara terus - menerus dengan memperhatikan manajemen baik pakan, perkembangan biakan, kontruksi kandang dan obat-obatan). Akan tetapi hasil penelitian belum maksimal dalam manajeman yaitu 1) hijauan yang diberikan pada umumnya berupa rumput lapangan, sedangkan Sebagian kecil responden memberikan pakan tambahannya berupa dedak, ampas tahu atau ubi-ubian. 2) kontruksi kandang yang kurang sesuai dengan persyarat kandang yang baik, yaitu tidak ada sekat antara domba betina, anakan dengan jantan sehingga menimbulkan terjadinya inbreading. 3) obat-obatan yang diberikan yang tersedia di lingkungan sekitar rumah responden.

\section{Analisis Pendapatan}

Analisi pendapatan yang dibahas dalam penelitian ini meliputi : 1) Biaya Produksi 2) penerimaan, 3) Analisis Pendapatan dan revenue cost ratio yang akan dijelaskan 
dibawah ini.

Biaya produksi. Biaya produksi adalah biaya yang dikeluarkan oleh peternak untuk memelihara ternak domba. Biaya produksi terbagi menjadi dua yaitu biaya tetap dan biaya tidak tetap. Biaya tetap untuk pemeliharaan ternak domba meliputi biaya penyusutan kandang, penyusutan peralatan dan penyusutan biaya ternak.

Hasil penelitian ini perhitungan untuk rata-rata biaya penyusutan kandang sebesar Rp 673.636, biaya penyusutan peralatan kandang yang responden keluarkan yaitu sekop, arit, gerobak, dan ember mayoritas peternak mengeluarkan rata-rata biaya penyusutan peralatan kandang sebesar Rp 275.000. Anggota kelompok tani ternak Haur Kuning pemeliharaannya pembibitan dan penggemukan. Bibit ternak yang berjenis kelamin jantan maka akan digemukan sedangkan untuk bibit ternak betina yang berjenis kelamin betina maka akan dijadikan indukan. Indukan yang masih bisa beranak akan tetap dipertahankan peternak, maka dari itu kami melakukan perhitungan nilai penyusutan ternak. Rata-rata biaya penyusutan ternak sebesar Rp 314.545.

Biaya Tidak Tetap (Variabel). Biaya variabel yang dikeluarkan yaitu biaya pakan, dan biaya obat. Rata-rata biaya pakan yang dikeluarkan oleh responden sebesar $\mathrm{Rp}$ 350.000. Rendahnya biaya pakan untuk ternak dikarenakan 1) hijauan atau rumput yang diberikan kepada ternak berasal dari alam, responden akan meluangkan waktu untuk mengarit dilapangan atau lahan-lahan kosong. 2) memanfaatkan limbah hasil pertanian misal jerami padi, jagung dan ubi-ubian baik itu daun, batang dan (jagung atau ubinya). 3) terbatas modal yang dimiliki responden, sebagian kecil responden memberikan pakan tambahan seminggu atau sebulan ketika ternak akan dijual. Pakan tambahan ini berupa dedak, ampas tahu dan ubi-ubian. Rata-rata biaya obat yang dikeluarkan oleh responden yaitu kurang lebih dari Rp 11.818. Rendahnya biaya pengobatan untuk ternak dikarenakan 1) pertolongan pertama, responden akan memberikan obat ke ternak dengan obat untuk manusia misalnya apabila ternak kembung maka akan diberi obat maag. Apabila tidak sembuh baru responden memangil mantri hewan. 2) terbatasnya biaya. Biaya tenaga kerja adalah Rp 0 artinya biaya untuk tenaga kerja sama sekali tidak dikeluarkan dalam penelitian ini, dikarenakan tenaga kerja masih menggunakan keluarga sendiri (istri atau anak-anak).

Penerimaan. Penerimaan usaha ternak domba di kelompok tani ternak Haur Kuning yaitu penjualan ternak domba yang siap jual oleh peternak domba. Harga jual ternak bervariasi dengan harga jual sebesar Rp 800.000, Rp 1.550.000 dan Rp 2.550.000 per ekor. Hal ini sesuai dengan pendapat (Welerubun et al., 2015) dikutip dari Hermanto (1993) penerimaan rill merupakan jumlah hasil yang diterima dari hasil penjualan produk sedangkan penerimaan yang diperhitungkan berasal dari nilai tambah ternak. Ratarata penjualan ternak dalam bentuk hidup lewat pedagang pengumpul yang datang ke desa-desa dan sebagiannya lagi melakukan penjualan langsung ke luar desa atau pulau dalam keadaan terpaksa seperti domba sakit atau perlu dana segera.

\section{Analisis Pendapatan dan Revenue Cost Ratio}

Pendapatan merupakan suatu keuntungan yang diterima dari hasil penjualan produk dikurangi dengan total biaya produksi. Hasil dari pendapatan rata-rata anggota kelompok tani ternak Haur Kuning Pendapatan yang diterima rata-rata sebesar $\mathrm{Rp}$ 2.979.546 dengan rata-rata penjualan ternak domba 3 ekor (Tabel 2).

Adanya perbedaan pendapatan dikarenakan 1) Harga jual ternak yang diterima oleh peternak yaitu sebesar Rp 800.000/ekor, Rp 1.550.000/ekor dan Rp 2.550.000/ekor, 2) Jumlah ternak yang dijual dalam satu tahun terakhir dengan mayoritas adalah 3 ekor dan hanya satu orang yang dapat menjual 6 ekor. 3) dan jumlah total biaya yang dikeluarkan.

Hal ini sesuai dengan pendapat 
Tabel 2. Laporan Rugi Laba Usaha Ternak Domba di Kelompok Tani Haur Kuning

\begin{tabular}{lrr}
\hline Uraian & Jumlah (Rp) & Persentase (\%) \\
\hline Penerimaan & & \\
Penjualan Ternak domba & 4.604 .545 & 100,00 \\
\hline Total Peneriman & 4.604 .545 & \\
\hline Biaya Tetap & & \\
Biaya Penyusutan Kandang & 673.636 & 41,45 \\
Biaya Penyusutan Peralatan & 275.000 & 16,92 \\
Biaya Penyusutan Ternak & 314.545 & 19,35 \\
\hline Total Biaya Tetap & 1.263 .181 & 77,73 \\
\hline Biaya Tidak Tetap & 350.000 & 21,53 \\
Biaya Pakan & 11.818 & 0,74 \\
Biaya Obat-obatan & 0 & 0,00 \\
Biaya Tenaga Kerja & 361.818 & 22,27 \\
Total Biaya Tidak Tetap & 1.624 .999 & 100,00 \\
\hline Total Biaya & 2.979 .546 & \\
\hline Pendapatan & 2,83 & \\
\hline R/C & & \\
\hline
\end{tabular}

Sumber: Data olahan 2018

(Parwati, 2007) harga jual anakan berpengaruh terhadap pendapatan usaha ternak kambing yang diterima. Menurut (Ningsih et al., 2013) menyatakan bahwa banyaknya jumlah kepemilikan ternak berpengaruh pada pendapatan, semakin banyak kepemilikan ternak maka pendapatannya juga bertambah besar sedangkan apabila terjadi kerugian juga akan menerima kerugian pula.

Hasil ini dapat analisis $\mathrm{R} / \mathrm{C}$ ratio terendah rata-rata sebesar 2,83 artinya setiap peningkatan biaya yang dikeluarkan sebesar Rp 1 dapat menghasilkan penerimaan sebesar Rp 2.83. Menurut Pasaribu (2012) mengatakan bahwa Nilai R/C ratio menunjukan besar penerimaan yang akan diperoleh dari setiap rupiah yang akan dikeluarkan oleh petani untuk kegiatan usaha ternak domba.

\section{Faktor-Faktor yang mempengaruhi Pendapatan Usaha Ternak Domba di Kelompok Tani Haur Kuning}

Faktor - faktor yang mempengaruhi pendapatan usaha ternak domba digunakan analisis regresi berganda, dimana variabel bebas (Independent) adalah harga jual ternak (X1), jumlah ekor ternak dijual (X2), biaya pakan (X3) dan biaya obat (X4), Sedangkan yang menjadi variabel terikat (Dependent) yaitu pendapatan. dianalisis dengan menggunakan regeresi linier berganda. Hasil analisis dapat dilihat pada Tabel 3.

Persamaan regresi :

$$
\mathrm{Y}=\begin{aligned}
&-5885724.523+2.975590988 \mathrm{X} 1+ \\
& 1533743.934 \mathrm{X} 2-1.050714511 \mathrm{X} 3
\end{aligned}
$$

Hasil Analisis regresi menunjukan nilai $\mathrm{R}^{2}$ sebesar 0,9982 artinya $99,82 \%$ pendapatan usaha ternak domba ditentukan oleh harga jual ternak, jumlah ekor tenak dijual dan biaya pakan, sedangkan sisanya $0,18 \%$ di pengaruhi oleh faktor lain di luar model ini. Nilai $\mathrm{F}_{\text {hitung }}$ (1349.09691405135). dengan Significance F (4.97589571307792E-10) kurang dari $\alpha$ $(0,005)$ artinya diterima $\mathrm{H} 1$.

Nilai konstanta $\quad-5885724.523$ menunjukan bahwa apabila peternak tidak memperhatikan harga jual, jumlah ekor ternak, biaya pakan maka akan mengalami kerugian sebesar $\mathrm{Rp} \quad-5.885 .724 .523 /$ unit 
Vol. 21 (1): 1-9

Tabel 3. Faktor-faktor yang Mempengaruhi Pendapatan

\begin{tabular}{lccc}
\hline Variabel Independen & Coefficients & t Stat & P-value \\
\hline Intercept & -5885724.523 & -37.089 & $2.69278 \mathrm{E}-09$ \\
harga jual & 2.975590988 & 34.3957 & $4.55276 \mathrm{E}-09$ \\
jum ekor ternak yang dijual & 1533743.934 & 46.60884 & $5.47206 \mathrm{E}-10$ \\
Biaya Pakan & -1.050714511 & -5.91956 & 0.000587775 \\
\hline
\end{tabular}

Sumber: Data olahan 2018

Keterangan: $\mathrm{R}^{2}=0.9982$

$\mathrm{F}_{\text {hitung }}(1349.09691405135)$ dengan Significance F (4.97589571307792E-10)

usaha/tahun. Nilai $t_{\text {hitung }}$ (-37.089) dengan P-value 2.69278E-09 lebih kecil dari $\alpha$ 0,005 dengan demikian $\mathrm{H} 1$ diterima.

Analisis secara parsial menunjukan bahwa faktor harga jual ternak berpengaruh signifikan terhadap pendapatan usaha ternak domba. Nilai $\mathrm{t}_{\text {hitung }}$ (46.60884) dengan P-value 4.55276E-09 lebih kecil dari $\alpha$ 0,005 dengan demikian $\mathrm{H} 1$ diterima. Koefisien regresi harga jual ternak akan meningkatkan pendapatan sebesar Rp 2.975590988/unit usaha/tahun, artinya Semakin tinggi harga jual ternak maka akan semakin tinggi pendapatan yang diterima.

Jumlah ekor ternak yang dijual secara parsial berpengaruh signifikan terhadap pendapatan yang diterima usaha ternak domba. Nilai ${ }_{\text {hitung }}(47,98248)$ dengan P-value 5.47206E-10 lebih kecil dari $\alpha$ 0,005 dengan demikian H1 diterima. Koefisien regresi jumlah ternak yang dijual akan meningkatkan Rp.

Rp 1.533.743.934/unit/tahun, artinya semakin bertambahnya jumlah ekor ternak yang dijual maka akan semakin bertambah pendapatan yang diterima. Biaya pakan secara parsial berpengaruh signifikan terhadap pendapatan yang diterima usaha ternak domba. Nilai $\mathrm{t}_{\text {hitung }}(-5.91956)$ dengan P-value 0.000587775 lebih kecil dari $\alpha$ 0,005 dengan demikian $\mathrm{H} 1$ diterima. Koefisien regresi biaya pakan akan berkurang $\mathrm{Rp}$ 1.050714511/unit usaha/tahun, artinya semakin dikurangi biaya pakan yang dikeluarkan untuk pemeliharan usaha ternak domba maka akan semakin berkurang pendapatan yang diterima.

\section{KESIMPULAN DAN SARAN}

\section{Kesimpulan}

Hasil penelitian ini dapat disimpulkan bahwa rata-rata pendapatan yang diterima $\mathrm{Rp}$ 2.979.546 dengan rata-rata penjualan ternak domba 3 ekor dan rata-rata analisis $\mathrm{R} / \mathrm{C}$ ratio sebesar 2,83 . Analisis regresi berganda yaitu harga jual ternak, jumlah ternak yang dijual dan biaya pakan akan mempengaruhi terhadap besarnya pendapatan usaha ternak domba.

\section{Saran}

Usaha ternak domba secara instensif ini menguntungkan, untuk meningkatkan pendapatan yang diterima peternak perlu adanya pelatihan dan pedampingan secara berkelanjutan dari pihak pemerintah ataupun lembaga pendidikan (Universitas) tentang teknis (bibit,pakan, kandang, kesehatan, pengolahan limbah dan pemasaran).

\section{UCAPAN TERIMA KASIH}

Penulis menyampaikan ucapan terima kasih dan penghargaan yang sebesar-besarnya kepada Kemenristek Dikti yang telah memberikan dana melalui Hibah Program Proposal Dosen Pemula tahun 2017.

\section{DAFTAR PUSTAKA}

Badar, G.A, S.Rahayudan S.Kuswanyan.2014. Faktor Teknis, Sosial dan Ekonomi yang mempengaruhi Penerimaan Usaha Ternak Domba yang di Gembalakan. 
Crilla, L., Z. Moesa., M. P. Putri. 2010. Efisiensi produksi usaha peternakan domba di Desa Cibunian Kecamatan Pamij ahan Kabupaten Bogor. Media Peternakan 33 (1): 55-60.

Mastuti, S dan N.N. Hidayati. 2009. Peranan tenaga kerja perempuan dalam usaha ternak sapi perah Kabupaten Banyumas. JAP.11(1):40-47

Ningsih, Y., N. N. Hidayat dan O. E. Djatmiko. 2013. Analisis kontribusi pendapatan dan efisiensi ekonomi usaha ayam niaga pedaging di Kabupaten Purbalingga. J. Ilmiah Peternakan. 1 (3): 1078-1085.

Parwati, I. A. P. 2007. Pendapatan dan faktor-faktor yang mempengaruhi produksi usaha ternak kambing dengan laserpunktur. Balai Pengkajian Teknologi Pertanian Bali. 7 (1): 1-14.
Pasaribu, Ali Musa. 2012. Perencanan dan Evaluasi Proyek agribisnis (Konsep dan Aplikasi). Lily Publisher. Yogyakarta.

Siswati A. K. Yogie. Rahayu S. dan Kuswaryan. S. 2015. Studi Kelayakan Finansial Usahaternak Domba Yang Dipelihara Secara Dikandangkan (Studi Kasus Di Desa Cibuntu Kecamatan Pasawahan Kabupaten Kuningan). Jurnal Ilmu Ternak, Desember 2015, Vol.15, No.2.

Soekartawi. 1996. Ilmu Usahatani dan Pengembangan Petani Kecil. University Indonesia Press, Jakarta

Welerubun, I.n. T. Ekowati. A.Setiadi.2016. Analisis Profitabilitas Usaha ternak Domba Kisar di Pulau Kisar Kabupaten Maluku Barat Daya. Jurnal Mediaagro Vol 12 no 2 Hal 39 - 47. 